\title{
Pro- and Anti-Inflammatory Cytokines during Immune Stimulation: Modulation of Iron Status and Red Blood Cell Profile
}

\author{
A. M. Koorts, ${ }^{1}$ P. F. Levay, ${ }^{2}$ P. J. Becker, ${ }^{1,3}$ and M. Viljoen ${ }^{1}$ \\ ${ }^{1}$ Department of Physiology, School of Medicine, Faculty of Health Sciences, University of Pretoria, P.O. Box 2034, \\ Pretoria 0001, South Africa \\ ${ }^{2}$ Department of Internal Medicine, Kalafong Hospital, University of Pretoria, Pretoria 0001, South Africa \\ ${ }^{3}$ Biostatistics Unit, Medical Research Council, Pretoria 0001, South Africa \\ Correspondence should be addressed to A. M. Koorts, akoorts@medic.up.ac.za
}

Received 2 November 2010; Revised 10 January 2011; Accepted 23 January 2011

Academic Editor: Jan van Amsterdam

Copyright ( 2011 A. M. Koorts et al. This is an open access article distributed under the Creative Commons Attribution License, which permits unrestricted use, distribution, and reproduction in any medium, provided the original work is properly cited.

Forty-eight patients were subdivided according to C-reactive protein (CRP) levels, resulting in 19 patients with normal (2.8 \pm $2.8 \mathrm{mg} / \mathrm{L})$ and 29 with elevated $(82.2 \pm 76.2 \mathrm{mg} / \mathrm{L})$ CRP levels. The elevated CRP group had iron and red blood cell (RBC) profiles characteristic of chronic immune stimulation (CIS), and the normal CRP group, profiles of true iron deficiency. Normal relationships between storage iron, bioavailable iron, and RBC indices were absent in the elevated CRP group-implying the role of iron as major determinant of the RBC profile to be diminished during CIS. The elevated CRP group had significant increases in proinflammatory cytokines (INF- $\gamma$, TNF- $\alpha$, Il-1 $\beta$, Il-6, and Il-8). Anti-inflammatory cytokine levels were normal, except for Il-10, supporting previous indications that Il-10 contributes to reducing bioavailable iron. Regression analysis suggested decreases in transferrin to be related to increases in Il- 8 and an increase in ferritin to be related to a decrease in Il-12 levels. TGF- $\beta$ levels were positively related to transferrin and negatively to ferritin.

\section{Introduction}

Cytokine production is a feature of immune stimulation, and alterations in the cytokine profile can influence both the iron status and red blood cell profile. Chronic immune stimulation is often associated with a decrease in serum iron. Depending on the cause of the immune stimulation, the purpose of this decrease is to reduce the bioavailability of iron in order to stem uncontrolled cellular proliferation, to reduce excessive production of reactive oxygen radicals and/or to withhold iron from pathogenic microorganisms. The effects of cytokines on iron bioavailability are largely mediated through a reduction in duodenal absorption of iron and a shift in the handling of iron by the macrophage in favour of iron storage. The latter can, in time, lead to hypoferraemia [1-3] and haemosiderosis of the macrophage $[2,4,5]$. This reduction in bioavailable iron can contribute to the anaemia of chronic disease (ACD).
It is commonly accepted that duodenal absorption of iron is decreased during chronic immune stimulation [6], and that cytokines are involved [7]. Under normal conditions, absorbed $\mathrm{Fe}^{2+}$ joins the intracellular labile iron pool of the enterocyte from where it can either be stored in the iron storage protein, ferritin, of the enterocyte, or translocated to the basolateral membrane for transport into the circulation $[8,9]$. With chronic immune stimulation the expression of enterocyte ferritin is upregulated, resulting in excessive sequestration and entrapment of iron within the enterocyte [10]. This newly acquired enterocyte iron will subsequently be expelled from the body during sloughing of the lining of the gastrointestinal tract. In addition, the numbers of the basolateral membrane iron exporter, ferroportin, are reduced thus blocking the entry of absorbed iron into the circulation. Ferroportin expression is downregulated by the acute phase protein, hepcidin. Hepcidin release is stimulated by the cytokine interleukin- 6 [11]. 
Iron circulates between the iron-containing compartments (intercellular iron shuttling) bound to the plasma iron transport protein transferrin. Transferrin is a negative acute phase protein, and as such serum transferrin is reduced during immune stimulation [6] resulting in less iron being available for cellular processes. Although interleukin- 6 is the major cytokine responsible for the regulation of acute phase protein synthesis during chronic immune stimulation [12], other cytokines, including interleukin-1 $\beta$, tumor necrosis factor- $\alpha$, and interleukin- 8 , have also been found to moderately influence the synthesis of acute phase proteins [12-14].

Ferritin, the major intracellular protein responsible for the storage of macrophage iron, plays a major role in the establishment and maintenance of an iron transfer block in the macrophage and thus in the hypoferraemic state of chronic immune stimulation. Ferritin up-regulation precedes the reduction in serum iron [15]. The proinflammatory cytokines tumor necrosis factor- $\alpha$, interleukin$1 \beta$, interleukin- 6 , and the anti-inflammatory cytokine interleukin-10 have all been shown to directly stimulate the transcription and translation of ferritin [16-18]. Cytokines not only upregulate ferritin expression, but also stimulate the macrophage to increase its uptake of iron by increasing the expression of the divalent metal transporter 1. Interferon- $\gamma$ has been shown to stimulate the uptake of ferrous iron by macrophages. In addition, the anti-inflammatory cytokines, interleukin-4 and interleukin-10, can upregulate transferrin receptor expression, resulting in an increase in transferrin receptor-mediated uptake of iron by the macrophage $[6,18]$. The macrophage obtains most of its iron by the degradation of haemoglobin and phagocytosis, and degradation of senescent erythrocytes is known to increase during chronic immune stimulation. This process is directly upregulated by tumor necrosis factor- $\alpha$ that stimulates the expression of C3bi (CD11b/CD18) receptors-the receptors responsible for the recognition and uptake of damaged erythrocytes. In addition, tumor necrosis factor- $\alpha$ can also indirectly upregulate this process by damaging circulating erythrocytes. These damaged erythrocytes are then phagocytosed upon binding to C3bi (CD11b/CD18) receptors $[6,18]$. Not only is haemoglobin iron obtained by degradation of red blood cells, but free plasma haemoglobin is taken up by the haemoglobin scavenger receptor, CD163. Interleukin10 and interleukin-6 augment macrophage haemoglobin acquisition by stimulating the expression of the haemoglobin scavenger receptor, CD163 [18]. In addition to increased uptake of iron by the macrophage during immune stimulation, release of iron is also reduced. Interferon- $\gamma$ contributes to this by downregulating the expression of ferroportin, the major transmembrane protein responsible for the release of macrophage iron [18] - a process that is also affected by hepcidin [19]. Many proinflammatory mediated effects on iron homeostasis are counterbalanced by anti-inflammatory cytokines such as interleukin-4 and interleukin-13 [18].

The aim of this study was to investigate the pro- and antiinflammatory cytokine status and the possible relationship of these cytokines to the iron status and red blood cell profiles in patients with chronic immune stimulation. A diverse group of patients with chronic disease was divided into two groups based on their C-reactive protein levels and then evaluated in terms of their iron status, red blood cell profiles, and proand anti-inflammatory cytokines.

\section{Materials and Methods}

2.1. Patients. The study group consisted of 48 patients attending the Department of Internal Medicine, Kalafong Hospital, South Africa, for treatment of chronic diseases. Blood and bone marrow were collected from each patient. The diagnosis of the patients were diverse and included various types of infections (tuberculosis (TB), malaria, human immunodeficiency virus (HIV)), cancers (lung, breast), pancytopenias as a result of bone marrow suppression or peripheral destruction of blood cells, organ failures including renal failure, heart failure and liver failure, anaemias with different etiologies, and various other pathologies. This resulted in an extremely heterogenous group of patients. The diagnosis and HIV status of all patients are presented in Table 1. Patients were subdivided based on their Creactive protein levels. Ethical clearance for the study was obtained from the Faculty of Health Sciences Research Ethics Committee, University of Pretoria (ethical clearance number $118 / 2003$ ), and all patients gave informed consent.

2.2. C-Reactive Protein (CRP). CRP levels were determined by a CRP ELISA (DRG Diagnostics, Germany, Orb Diagnostics, Modderfontein, South Africa).

2.3. Cytokines. Interleukin- 8 (Il-8), interleukin- $1 \beta$ (Il-1 $\beta)$, interleukin-6 (Il-6), interleukin-10 (Il-10), tumor necrosis factor- $\alpha$ (TNF- $\alpha$ ), and interleukin-12p70 (Il-12) were determined by the Human Inflammation Kit, BD Cytometric Bead Array (CBA) (The Scientific group, Midrand, South Africa). Interleukin-2 (Il-2), interleukin-4 (Il-4), interleukin5 (Il-5), interleukin-10 (Il-10), tumor necrosis factor- $\alpha$ (TNF- $\alpha$ ), and interferon- $\gamma$ (INF- $\gamma$ ) were determined by the BD Cytometric Human T-helper cell type-1/T-helper cell type-2 Cytokine Kit (The Scientific group, Midrand, South Africa). With the T-helper cell type-1/T-helper cell type-2 CBA cytokine kit, the interferon- $\gamma$ standards were lost and the measurement of INF- $\gamma$ was done by the human INF- $\gamma$ ELISA Kit, BD OptEIA test (The Scientific group, Midrand, South Africa). Il-10 and TNF- $\alpha$ were measured in both the Human Inflammation kit and the Human T-helper cell type1/T-helper cell type-2 kit. The mean of these values were calculated and used for statistical analysis. Transforming growth factor- $\beta 1$ (TGF- $\beta 1$ ) was determined by a TGF- $\beta 1$ ELISA (DRG Diagnostics, Germany, Orb Diagnostics, Modderfontein, South Africa). Granulocyte macrophage-colony stimulating factor (GM-CSF) was determined by a GMCSF ELISA (DRG Diagnostics, Germany, Orb Diagnostics, Modderfontein, South Africa).

2.4. Serum Iron Markers. Serum iron markers were determined by the Chemical Pathology laboratory, National Health Laboratory Services (NHLS), University of Pretoria, South Africa. 
2.5. Soluble Transferrin Receptor. The soluble transferrin receptor was determined by an ELISA from Ramco Laboratories, Inc., Texas, USA.

\subsection{Prussian Blue Iron Stains of Bone Marrow Aspirates and Core Bone Marrow Biopsies}

2.6.1. HCl-Ferrocyanide Iron Stains of Bone Marrow Aspirate Smears. The iron stains and evaluation of the bone marrow aspirate smears were performed by the Haematology laboratory, NHLS, University of Pretoria, South Africa.

2.6.2. HCl-Ferrocyanide Iron Stains of Core Bone Marrow LR White Plastic Sections. A piece of core bone marrow was obtained during the time the patients had their biopsies, taken for diagnostic purposes, and placed immediately in the fixative on ice. The fixative consisted of $4 \%$ formaldehyde (FA) and $0.05 \%$ glutaraldehyde (GA) in a $0.15 \mathrm{M}$ sodium phosphate buffer. The fixative was prepared fresh immediately prior to the obtainment of bone marrow tissue. A $10 \%$ paraformaldehyde solution in deionised $\mathrm{H}_{2} \mathrm{O}$ was prepared fresh in a fume hood (Paraformaldehyde (Trioxymethylene), SPI Supplies, cat. no. 2615, Rick Loveland \& Associates, Halfway House, South Africa). The solution was heated to $60-70^{\circ} \mathrm{C}$ with constant stirring. Once the solution had reached the proper temperature stirring was continued for 15 minutes. At this point, the solution was milky. One to two drops of $1 \mathrm{~N} \mathrm{NaOH}$ was added, with stirring, until the solution cleared [20]. The $0.15 \mathrm{M}$ sodium phosphate buffer was prepared from two stock solutions, a $0.3 \mathrm{M} \mathrm{Na}_{2} \mathrm{HPO}_{4}$ stock solution (di-Sodium hydrogen phosphate Dihydrate, Fluka, BioChemika, Ultra, cat. no. 71643, Sigma-Aldrich, Aston Manor, South Africa) and a $0.3 \mathrm{M} \mathrm{NaH}_{2} \mathrm{PO}_{4}$ stock solution (Sodium dihydrogen phosphate Dihydrate, Fluka, Biochemika, MicroSelect, cat. no. 71505, Sigma-Aldrich, Aston Manor, South Africa). The $0.3 \mathrm{M} \mathrm{NaH}_{2} \mathrm{PO}_{4}$ stock solution was added to the $0.3 \mathrm{M} \mathrm{Na}_{2} \mathrm{HPO}_{4}$ stock solution to a $\mathrm{pH}$ of 7.25 immediately prior to the obtainment of bone marrow tissue. This $0.3 \mathrm{M}$ sodium phosphate buffer solution was then diluted $1: 1$ with the $10 \%$ freshly prepared formaldehyde stock solution and deionised $\mathrm{H}_{2} \mathrm{O}$. This was followed by the addition of the GA (Pure Glutaraldehyde $25 \%$ solution, E.M. grade, SPI Supplies, cat. no. 2607, Rick Loveland \& Associates, Halfway House, South Africa). The bone marrow tissue was fixed for 24 hours at $6^{\circ} \mathrm{C}$ in this fixative. All subsequent steps were carried out at $6^{\circ} \mathrm{C}$ with rotation (TAAB rotator, Wirsam Scientific, Richmond, South Africa). After 24 hours, the bone marrow tissue was washed 3 times for 20 minutes with the sodium phosphate buffer. It was then dehydrated as follows: $50 \% \mathrm{EtOH}, 70 \% \mathrm{EtOH}, 30$ minutes each, followed by $85 \% \mathrm{EtOH}$, twice for 15 minutes each (Ethanol 99.9\% Absolute A.R., Minema, Rick Loveland \& Associates, Halfway House, South Africa). Subsequently, the bone marrow tissue was infiltrated with a $1: 185 \%$ EtOH : LR White mixture for 30 minutes. LR White dissolved in $85 \% \mathrm{EtOH}$ but not in $80 \% \mathrm{EtOH}$ (LR White Resin, medium grade acrylic resin, London Resin Company LTD., Rick Loveland \& Associates, Halfway House, South Africa).
The bone marrow tissue was infiltrated with LR White, twice for 30 minutes each. The tissue was then placed in gelatine capsules in fresh LR White ensuring no air bubbles and polymerised for 24 hours at $50^{\circ} \mathrm{C}$ (Gelatine capsules, SPI Supplies, cat. no. 2302, Rick Loveland \& Associates, Halfway House, South Africa). The block of bone marrow tissue was sectioned into $2 \mu \mathrm{m}$ thick sections which were then placed on microscope slides (Menzel-Glaser Superfrost Plus Microscope Slides, Labotec, Halfway House, South Africa). The slides were rinsed in deionised $\mathrm{H}_{2} \mathrm{O}$ before the staining procedure. The sections were stained for 1 hour in $10 \%$ ferrocyanide $/ 10 \% \mathrm{HCl}$ prepared just before use in Coplin jars at $25^{\circ} \mathrm{C}(10 \%$ ferrocyanide, Potassium hexacyanoferrate (II) Trihydrate, Fluka, Biochemika Ultra, cat. no. 60279, SigmaAldrich, Aston Manor, South Africa; $10 \% \mathrm{HCl}$, Hydrochloric acid 30\%, Riedel-de-Haën, cat. no. 30053, Sigma-Aldrich, Aston Manor, South Africa). After the staining step, the slides were rinsed in deionised $\mathrm{H}_{2} \mathrm{O}$. The sections were counterstained with $1 \%$ eosin in $70 \%$ ethanol (acidified) for 10 minutes (1\% eosin, Eosin yellowish, Gurr, Microscopy Material, cat. no. 45380, BDH Chemicals Ltd., England, in $70 \%$ ethanol, acidified with acetic acid). Once again, the slides were rinsed in deionised $\mathrm{H}_{2} \mathrm{O}$. Finally, the slides were air-dried on a hot plate and mounted with immersion oil and a cover slide.

2.7. Red Blood Cell Profile. Red blood cell counts, haemoglobin concentration, mean corpuscular volume (MCV), mean corpuscular haemoglobin $(\mathrm{MCH})$, mean corpuscular haemoglobin concentration (MCHC), and red blood cell distribution width (RDW) were determined by the NHLS, University of Pretoria, South Africa.

2.8. Statistical Analysis. The ranksum test was employed on $\log$ transformed data. This was done due to the skewness of the data sets. For summary statistics, the geometric mean and the $95 \%$ confidence interval were reported. Pearson's product-moment correlation coefficient $(r)$ was employed to assess dependence between study parameters. Testing was done at the 0.05 level of significance. Forward stepwise regression with $p e=0.2$ as the entrance point was employed to investigate the relationship between each of the iron status and red blood cell profile parameters and the pro- and antiinflammatory cytokines. pe specifies the significance level for addition to the model; thus, terms with $P<.2$ are eligible for addition. The discrepancy between $R^{2}$ and adjusted $R^{2}$ was due to the small sample size.

\section{Results}

The patients were subdivided according to the immunological indicator C-reactive protein into a group with normal $(\leq 10 \mathrm{mg} / \mathrm{L})$ and a group with elevated $(>10 \mathrm{mg} / \mathrm{L})$ C-reactive protein levels. This resulted in a group of 19 patients with normal C-reactive protein $(2.8 \pm 2.8 \mathrm{mg} / \mathrm{L})$ and a group of 29 patients with elevated C-reactive protein $(82.2 \pm 76.2 \mathrm{mg} / \mathrm{L})$. The average and SD for age for the group of patients with elevated C-reactive protein was $41.6 \pm 15.9$ years and for the 
group of patients with normal C-reactive protein $42.3 \pm 15.2$ years. The majority of patients were black females, with the exception of four males and three whites and six males and one white in the elevated C-reactive protein and normal Creactive protein groups, respectively.

The results for the pro- and anti-inflammatory cytokines are presented in Table 2. Various proinflammatory cytokines including INF- $\gamma$, TNF- $\alpha$, Il- $1 \beta$, Il-6, and Il- 8 were elevated in the group of patients with elevated C-reactive protein compared to the group of patients with normal C-reactive protein. No significant differences were shown for the proinflammatory cytokines Il-2 and Il-12. The Thelper cell type- 2 cytokines involved in predominantly antiinflammatory processes including Il-4, Il-5 and TGF- $\beta$, were not significantly different between the group of patients with elevated C-reactive protein and the group of patients with normal C-reactive protein. However, the T-helper cell type2 cytokine, Il-10, was significantly higher in the group of patients with elevated C-reactive protein compared to the group of patients with normal C-reactive protein.

The iron status of the group of patients with elevated Creactive protein was characteristic of patients with a chronic proinflammatory immune status. The serum iron markers and soluble transferrin receptor for the two groups of patients are shown in Table 3. Serum transferrin levels were significantly lower, serum ferritin significantly higher, and soluble transferrin receptor significantly lower in the group with elevated C-reactive protein.

When the red blood cell profiles of the group with normal C-reactive protein and the group with elevated Creactive protein were compared (Table 4 ), it was seen that both groups were anaemic, but that the $\mathrm{MCV}, \mathrm{MCH}$, and the MCHC were significantly lower in the group of patients with normal C-reactive protein. The RDW did not differ significantly between the groups, but was higher than normal for both groups.

To assess total body iron stores, in order to distinguish between true iron deficiency and an iron transfer block, a Prussian blue iron stain was performed on the bone marrow aspirates and bone marrow cores. Results can be seen in Table 5 .

Various correlations were shown between storage iron, bioavailable iron, and red blood cell production in the group of patients with normal C-reactive protein. None of these correlations could be demonstrated in the group of patients with elevated C-reactive protein (refer to Table 6).

The dependence of various serum iron markers, soluble transferrin receptor, and red blood cell indices on pro- and anti-inflammatory cytokines in the group of patients with elevated C-reactive protein are presented in Table 7.

\section{Discussion}

C-reactive protein is an acute phase protein and rises sharply with the onset of inflammation reaching peak concentrations within 24-48 hours. Inflammatory processes accompanying tissue injury, infection, malignancy, autoimmune diseases, and cardiovascular diseases can all result in an increase in Creactive protein levels [21]. C-reactive protein is synthesised and secreted by hepatocytes upon stimulation by acute phase protein-inducing cytokines such as Il-6 [22]. In patients with elevated C-reactive protein, the macrophage takes on a proinflammatory role, which is characteristic of a T-helper cell type-1 immune response. An increase in C-reactive protein is thus seen as an indicator of the involvement of the classically activated macrophage (proinflammatory macrophage). C-reactive protein levels are considered by some as the most accurate reflection of the inflammatory state [23].

In the present study, patients with chronic disease were divided into two groups based on their C-reactive protein levels and then evaluated in terms of their iron status, red blood cell profiles, and pro- and anti-inflammatory cytokines.

Iron status was evaluated by Prussian blue iron stains of bone marrow aspirates and cores, by levels of serum iron markers, and by red blood cell indices. The results are shown in Tables 3, 4, and 5. In the group of patients with high C-reactive protein levels, a high prevalence of iron transfer block was found when all factors were considered. The prevalence was $69 \%$ for the patients with elevated C-reactive protein, in contrast to the $26 \%$ for the group with normal C-reactive protein levels. The majority of the patients with high C-reactive protein levels had serum iron profiles characteristic of patients with an iron transfer block [6], that is, a decrease in serum iron, an increase in ferritin, a decrease in transferrin, a small increase in soluble transferrin receptor, a decrease in transferrin/log ferritin ratio, and a decrease in soluble transferrin receptor/log ferritin ratio. As was expected, most of the patients with normal C-reactive protein did not have serum iron profiles characteristic of an iron transfer block. However, these patients had a high incidence of true iron deficiency. For these patients, a decreased serum iron, normal ferritin, normal transferrin, a marked increase in soluble transferrin receptor, an increase in transferrin/log ferritin ratio, and an increase in the soluble transferrin receptor/log ferritin ratio were shown.

Chronic immune stimulation has a negative effect on red blood cell production. Immune-stimulated decreases in bioavailable iron contribute, but other factors, mostly cytokine-induced, are also involved. Such factors include suppression of the proliferation of erythroid progenitor cells, a decrease in the synthesis of erythropoietin, a decrease in the sensitivity of erythroblasts to erythropoietin, and shortened red blood cell life span [24-26]. The anaemia of chronic disease is, therefore, on the one hand, the result of a decrease in iron reaching the erythron and, on the other, that of a suppression of red blood cell synthesis [24-26].

In this study, anaemia was present in the majority of patients, irrespective of their C-reactive protein levels. In the patients with normal C-reactive protein the inclusion of a couple of patients with different red blood cell pathologies, such as macrocytic anaemia, resulted in a normal mean corpuscular volume for the group. However, both the mean corpuscular haemoglobin and mean corpuscular haemoglobin concentration were decreased, which is characteristic of the anaemia of true iron deficiency. In the patients with elevated C-reactive protein, the average for the mean corpuscular 
TABle 1: Diagnosis and HIV status of the patients (*elevated CRP).

\begin{tabular}{|c|c|c|}
\hline Patient & Diagnosis & HIV \\
\hline $1 *$ & Pneumonia and sepsis, Escherichia coli and urinary tract infection and acute renal failure & pos \\
\hline $2^{*}$ & Heart failure and megaloblastic anaemia and pernicious & neg \\
\hline $3^{*}$ & $\begin{array}{l}\text { Anaemia and idiopathic thrombocytic purpura and acute haemolytic anaemia versus disseminated } \\
\text { intravascular coagulopathy, post mortem }\end{array}$ & pos \\
\hline $4^{*}$ & Carcinoid cancer and pneumonia and metastasis to the brain & neg \\
\hline $5^{*}$ & Idiopathic vasculitis and pancytopenia questioning antiphospholipid syndrome and uterine mass & neg \\
\hline 6 & Malaria and idiopathic thrombocytic purpura & neg \\
\hline $7^{*}$ & Cruveilhier-Baumgarten disease and hypersplenism and TB & neg \\
\hline $8^{*}$ & Lung cancer and acute renal failure and pneumonia & neg \\
\hline $9^{*}$ & Pneumonia, Escherichia coli & pos \\
\hline 10 & Idiopathic thrombocytic purpura and iron deficient anaemia and questioning systemic lupus erythematosus & neg \\
\hline $11^{*}$ & Retroviral disease and renal failure & pos \\
\hline 12 & Metastatic breast cancer & neg \\
\hline $13^{*}$ & Pneumonia and confusion & pos \\
\hline $14^{*}$ & Pulmonary TB and effusion & pos \\
\hline 15 & Megaloblastic anaemia & neg \\
\hline 16 & Anaemia due to blood loss & neg \\
\hline 17 & Retroviral disease and anaemia and Kaposi's sarcoma and previous pulmonary TB & pos \\
\hline $18^{*}$ & Antiphospholipid syndrome and haemolytic anaemia & neg \\
\hline $19^{*}$ & Retroviral disease and bicytopenia and mycobacterium avium complex & pos \\
\hline $20^{*}$ & $\begin{array}{l}\text { Retroviral disease and anaemia and dilated cardiomyopathy and antiphospholipid syndrome and TB and } \\
\text { thrombosis }\end{array}$ & pos \\
\hline $21^{*}$ & Retroviral disease and TB and sepsis and anaemia and ascitis & pos \\
\hline $22^{*}$ & Chronic obstructive pulmonary disease and liver and kidney failure and pelagra and sepsis and ethanol abuse & neg \\
\hline $23^{*}$ & Retroviral disease and pneumonia and pancytopenia & pos \\
\hline 24 & Idiopathic thrombocytic purpura & neg \\
\hline 25 & $\begin{array}{l}\text { Retroviral disease and diabetes mellitus and heart failure and obesity and splenomegaly and lymphadenopathy } \\
\text { and TB, bone marrow }\end{array}$ & pos \\
\hline $26^{*}$ & $\begin{array}{l}\text { Ethanol abuse and radial fracture and pulmonary TB and bradycardia and primary hypertension, increase } \\
\text { calcium }\end{array}$ & neg \\
\hline 27 & Massive splenomegaly and pancytopenia & neg \\
\hline $28^{*}$ & Megaloblastic anaemia and syphilis & neg \\
\hline $29^{*}$ & Delerium and $\mathrm{TB}$ and calcified nodes, post mortem $=$ miliary $\mathrm{TB}$ & neg \\
\hline $30^{*}$ & OD and thrombocytopenia and macrocytosis and ethanol abuse & neg \\
\hline $31^{*}$ & Retroviral disease and pulmonary TB and pancytopenia & pos \\
\hline 32 & Nephritis: hypertension, edema, proteinuria & neg \\
\hline $33^{*}$ & Pancytopenia and ascitis and TB and proteinuria and urinary tract infection and sepsis, ICU & neg \\
\hline $34^{*}$ & Retroviral disease and Hodgkin's disease and TB & pos \\
\hline 35 & Hypertension and diabetes mellitus and leucocytosis, persistent & neg \\
\hline $36^{*}$ & Retroviral disease on HAART and pulmonary TB & pos \\
\hline 37 & Retroviral disease and idiopathic thrombocytic purpura-immune, normal spleen & pos \\
\hline 38 & Megaloblastic anaemia and hypothyroidism & neg \\
\hline 39 & Anaemia & neg \\
\hline $40^{*}$ & Anaemia and pyrexia and miliary $\mathrm{TB}$, bone marrow culture & pos \\
\hline 41 & Pancytopenia and idiopathic thrombocytic purpura & pos \\
\hline 42 & Iron-deficient anaemia & neg \\
\hline 43 & Iron-deficient anaemia and peptic ulcer disease and pneumonia, Staphylococcus aureus & neg \\
\hline $44^{*}$ & Idiopathic 4-limb African gangrene & neg \\
\hline 45 & Retroviral disease and pneumonia and pancytopenia & pos \\
\hline
\end{tabular}


TABle 1: Continued.

\begin{tabular}{lll}
\hline Patient & Diagnosis & HIV \\
\hline $46^{*}$ & Monoclonal gammopathy of undetermined significance and uterine mass & neg \\
$47^{*}$ & Retroviral disease and pancytopenia and pneumonia & pos \\
48 & Idiopathic thrombocytic purpura and bicytopenia & neg \\
\hline
\end{tabular}

TABle 2: Cytokine levels for patients with elevated C-reactive protein and patients with normal C-reactive protein.

\begin{tabular}{|c|c|c|c|}
\hline & $\begin{array}{c}\text { Elevated CRP } \\
\quad(n=28) \\
\text { Geometric mean; } \\
\text { 95\% confidence } \\
\text { interval }\end{array}$ & $\begin{array}{c}\text { Normal CRP } \\
\quad(n=19) \\
\text { Geometric mean; } \\
\text { 95\% confidence } \\
\text { interval }\end{array}$ & $P$-value \\
\hline INF- $\gamma$ & $\begin{array}{c}2.00 \\
0.76-5.27\end{array}$ & $\begin{array}{c}0.18 \\
0.09-0.37\end{array}$ & .001 \\
\hline TNF- $\alpha$ & $\begin{array}{c}3.47 \\
2.78-4.32\end{array}$ & $\begin{array}{c}2.29 ; \\
1.88-2.78\end{array}$ & .009 \\
\hline Il- $1 \beta$ & $\begin{array}{c}1.81 \\
0.92-3.57\end{array}$ & $\begin{array}{c}0.49 \\
0.26-0.92\end{array}$ & .008 \\
\hline Il-6 & $\begin{array}{c}79.23 ; \\
36.69-171.09\end{array}$ & $\begin{array}{c}3.56 \\
2.08-6.09\end{array}$ & .000 \\
\hline Il-12 & $\begin{array}{c}2.69 ; \\
1.69-4.28\end{array}$ & $\begin{array}{c}2.73 ; \\
1.50-4.99\end{array}$ & .97 \\
\hline Il-2 & $\begin{array}{c}7.41 ; \\
4.85-11.33\end{array}$ & $\begin{array}{c}5.04 ; \\
2.45-10.37\end{array}$ & .31 \\
\hline Il-8 & $\begin{array}{c}88.12 ; \\
49.84-155.80\end{array}$ & $\begin{array}{c}14.20 \\
8.80-22.91\end{array}$ & .000 \\
\hline GM-CSF & $\begin{array}{c}2.15 ; \\
1.21-3.81\end{array}$ & $\begin{array}{c}2.58 \\
0.89-7.44\end{array}$ & .73 \\
\hline Il-4 & $\begin{array}{c}1.74 \\
1.21-2.51\end{array}$ & $\begin{array}{c}1.48 ; \\
0.87-2.50\end{array}$ & .59 \\
\hline Il-5 & $\begin{array}{c}2.35 \\
1.74-3.16\end{array}$ & $\begin{array}{c}2.23 ; \\
1.18-4.19\end{array}$ & .86 \\
\hline TGF- $\beta$ & $\begin{array}{c}10.51 ; \\
8.34-13.24\end{array}$ & $\begin{array}{c}8.60 \\
6.34-11.67\end{array}$ & .28 \\
\hline Il-10 & $\begin{array}{c}9.37 ; \\
5.66-15.51\end{array}$ & $\begin{array}{c}4.56 \\
3.29-6.32\end{array}$ & .034 \\
\hline
\end{tabular}

volume corresponded to that of a normocytic red blood cell profile. It is known that patients with the anaemia of chronic disease (ACD) often exhibit a normocytic, normochromic anaemia when they are initially seen in medical care facilities $[6,27]$. With further development of ACD, these patients develop a microcytic, hypochromic anaemia. In view of the iron status of the two groups, it would be reasonable to assume that the group with normal $\mathrm{C}$-reactive protein had true iron deficiency anaemia, while the anaemia of the high C-reactive protein group was predominantly that of chronic disease. Il- $1 \beta$, TNF- $\alpha$, and TGF- $\beta$ have been shown to inhibit erythropoietin synthesis and action [28]. In the present study, there were, as will be discussed later, increases in Il- $1 \beta$ and TNF- $\alpha$ levels in the group of patients with high C-reactive protein levels.
An important difference with regard to the relationship between iron availability and the red blood cell profile was observed between the group with elevated C-reactive protein levels and that with normal levels. The normal expected relationships were found in the group with normal Creactive protein levels. For instance, the correlations between transferrin saturation and $\mathrm{MCV}(0.62,0.005)$, transferrin saturation and $\mathrm{MCH}(0.64,0.003)$, and transferrin saturation and $\mathrm{MCHC}(0.49,0.033)$ supported the notion that an increase in the availability of iron has a positive effect on the red blood cell profile [29-31]. The negative correlations seen between serum transferrin and MCV $(-0.62,0.005)$, serum transferrin and $\mathrm{MCH}(-0.74,0.0003)$, and serum transferrin and $\mathrm{MCHC}(-0.79,0.001)$ reflected the fact that an increase in serum transferrin, related to iron-deficient iron stores, generally results in iron-deficient erythropoiesis [29-31]. In addition, the following negative correlations, between soluble transferrin receptor and MCV $(-0.65,0.002)$, soluble transferrin receptor and $\mathrm{MCH}(-0.75,0.0002)$, and soluble transferrin receptor and $\mathrm{MCHC}(-0.75,0.0002)$ demonstrated the increase in soluble transferrin receptor levels normally found with deficient red blood cell production [31]. These normal relationships did not exist in the high Creactive protein group (Table 6). The results of this study thus confirm bioavailability of iron to be a major determinant of the red blood cell profile. However, with pronounced proinflammatory activity (significantly elevated C-reactive protein), accompanied by an iron transfer block and ACD, this dominancy of bioavailable iron in the regulation of proper red blood cell production was lost.

In this study, results on the cytokine profiles supported the subdivision into a normal and a proinflammatory group on the basis of C-reactive protein levels. Most of the proinflammatory cytokines, including INF- $\gamma$, TNF- $\alpha$, Il- $1 \beta$, Il-6, and Il-8, were significantly higher in the group of patients with elevated C-reactive protein compared to the group of patients with normal C-reactive protein. These cytokines are known to play a role in the reduction of available iron during chronic immune stimulation. INF- $\gamma$ has, for instance, been shown to downregulate the expression of the transmembrane protein ferroportin [18]. Il-1 $\beta$, TNF$\alpha$, and Il- 6 have been reported to directly stimulate the transcription and translation of ferritin $[16,17]$, while Il- $1 \beta$, TNF- $\alpha$, Il-6, and Il-8 stimulation are known to contribute to the synthesis of acute phase proteins [12-14]. Furthermore, TNF- $\alpha$, has been shown to increase the acquisition of erythrocyte iron by the macrophage by increasing the expression of C3bi $(\mathrm{CD} 11 \mathrm{~b} / \mathrm{CD} 18)$ receptors $[6,18]$. Il6 , in addition to its role as major cytokine responsible for the regulation of acute phase protein synthesis [12], 
TABLE 3: Serum iron markers and soluble transferrin receptor for patients with elevated C-reactive protein and patients with normal Creactive protein.

\begin{tabular}{lcc}
\hline Normal laboratory values & $\begin{array}{c}\text { Elevated CRP }(n=28) \\
\text { Geometric mean; } \\
\text { 95\% confidence interval }\end{array}$ & $\begin{array}{c}\text { Normal CRP }(n=19) \\
\text { Geometric mean; } \\
\text { 95\% confidence interval }\end{array}$ \\
\hline Serum iron & $6.87 ;$ & $7.89 ;$ \\
$(10-30 \mu \mathrm{mol} / \mathrm{L})$ & $5.11-9.22$ & $5.15-12.08$ \\
Serum transferrin & $1.21 ;$ & $2.33 ;$ \\
$(2-3.6 \mathrm{~g} / \mathrm{L})$ & $1.04-1.41$ & $1.98-2.75$ \\
Transferrin saturation & $21.59 ;$ & $14.34 ;$ \\
$(15-50 \%$ f, $20-50 \% \mathrm{~m})$ & $14.90-31.26$ & $8.48-24.25$ \\
Serum ferritin & $928.70 ;$ & $44.97 ;$ \\
$(11-306.8 \mu \mathrm{g} / \mathrm{L}$ f, & $482.12-1788.95$ & $19.31-104.71$ \\
$23.9-336.2 \mu \mathrm{g} / \mathrm{L}$ m) & $0.43 ;$ & $1.59 ;$ \\
Transferrin/log ferritin & $0.34-0.54$ & $1.07-2.38$ \\
Soluble transferrin receptor & $7.41 ;$ & $13.38 ;$ \\
$(2.9-8.3 \mu \mathrm{g} / \mathrm{mL})$ & $5.69-9.67$ & $9.30-19.24$ \\
Soluble transferrin & $2.58 ;$ & $9.14 ;$ \\
receptor/log ferritin & $1.94-3.43$ & $5.22-16.00$ \\
\hline
\end{tabular}

TABLE 4: Red blood cell indices for patients with elevated C-reactive protein and patients with normal C-reactive protein.

\begin{tabular}{|c|c|c|c|}
\hline Normal laboratory values & $\begin{array}{c}\text { Elevated CRP }(n=28) \\
\text { Geometric mean; } \\
95 \% \text { confidence interval }\end{array}$ & $\begin{array}{c}\text { Normal CRP }(n=19) \\
\text { Geometric mean; } \\
95 \% \text { confidence interval }\end{array}$ & $P$-value \\
\hline $\begin{array}{l}\text { Red blood cell count } \\
\left(4.13-5.67 \times 10^{12} / \mathrm{L} \mathrm{f}, 4.89-6.11 \times 10^{12} / \mathrm{L} \mathrm{m}\right)\end{array}$ & $\begin{array}{c}2.33 \\
1.95-2.78\end{array}$ & $\begin{array}{c}2.62 \\
2.04-3.36\end{array}$ & .42 \\
\hline $\begin{array}{l}\text { Haemoglobin } \\
(12.1-16.3 \mathrm{~g} / \mathrm{dL} \text { f, } 14.3-18.3 \mathrm{~g} / \mathrm{dL} \mathrm{m})\end{array}$ & $\begin{array}{c}6.80 \\
5.66-8.16\end{array}$ & $\begin{array}{c}6.23 ; \\
4.74-8.19\end{array}$ & .57 \\
\hline $\begin{array}{l}\text { Haematocrit } \\
(0.370-0.490 \mathrm{~L} / \mathrm{L} \mathrm{f}, 0.430-0.550 \mathrm{~L} / \mathrm{L} \mathrm{m})\end{array}$ & $\begin{array}{c}0.21 \\
0.18-0.25\end{array}$ & $\begin{array}{c}0.21 \\
0.16-0.27\end{array}$ & .94 \\
\hline $\begin{array}{l}\text { Mean corpuscular volume } \\
(79.1-98.9 \mathrm{fL})\end{array}$ & $\begin{array}{c}\text { 90.05; } \\
84.42-96.05\end{array}$ & $\begin{array}{c}\text { 78.98; } \\
72.01-86.62\end{array}$ & .016 \\
\hline $\begin{array}{l}\text { Mean corpuscular haemoglobin } \\
(27-32 \mathrm{pg})\end{array}$ & $\begin{array}{c}29.24 \\
27.09-31.55\end{array}$ & $\begin{array}{c}23.82 ; \\
21.13-26.84\end{array}$ & .003 \\
\hline $\begin{array}{l}\text { Mean corpuscular haemoglobin } \\
\text { concentration }(32-36 \mathrm{~g} / \mathrm{dL})\end{array}$ & $\begin{array}{c}32.47 \\
31.70-33.26\end{array}$ & $\begin{array}{c}30.16 \\
29.00-31.38\end{array}$ & .001 \\
\hline $\begin{array}{l}\text { Red blood cell distribution width } \\
(11.6-14 \%)\end{array}$ & $\begin{array}{c}19.39 \\
17.48-21.51\end{array}$ & $\begin{array}{c}21.34 \\
18.38-24.77\end{array}$ & .27 \\
\hline
\end{tabular}

TABLE 5: Iron stores and prevalence of iron transfer block for patients with elevated C-reactive protein and patients with normal C-reactive protein.

\begin{tabular}{lcc}
\hline & $\begin{array}{c}\text { Elevated C-reactive } \\
\text { protein } \\
n=29\end{array}$ & $\begin{array}{c}\text { Normal C-reactive } \\
\text { protein } \\
n=19\end{array}$ \\
\hline Increased iron stores & $59 \%$ & $16 \%$ \\
Normal iron stores & $22 \%$ & $21 \%$ \\
Decreased iron stores & $19 \%$ & $63 \%$ \\
Iron transfer block & $69 \%$ & $26 \%$ \\
No iron transfer block & $31 \%$ & $74 \%$ \\
\hline
\end{tabular}

also stimulates the release of hepcidin [11], as well as the expression of the haemoglobin scavenger receptor, CD163 [18]. The proinflammatory cytokine results of this study are, therefore, in line with previous findings.

The only proinflammatory cytokines that were not significantly higher in the group of patients with elevated C-reactive protein were Il-2 and Il-12. This may perhaps be explained by the inclusion of many HIV-positive patients (15 of 29 patients) in this group. With human immunodeficiency virus infection, the production of both Il-2 and Il-12 are reduced $[32,33]$.

The T-helper cell type- 2 cytokines, Il-4, Il-5 and TGF$\beta$, were not significantly different between the patients with 


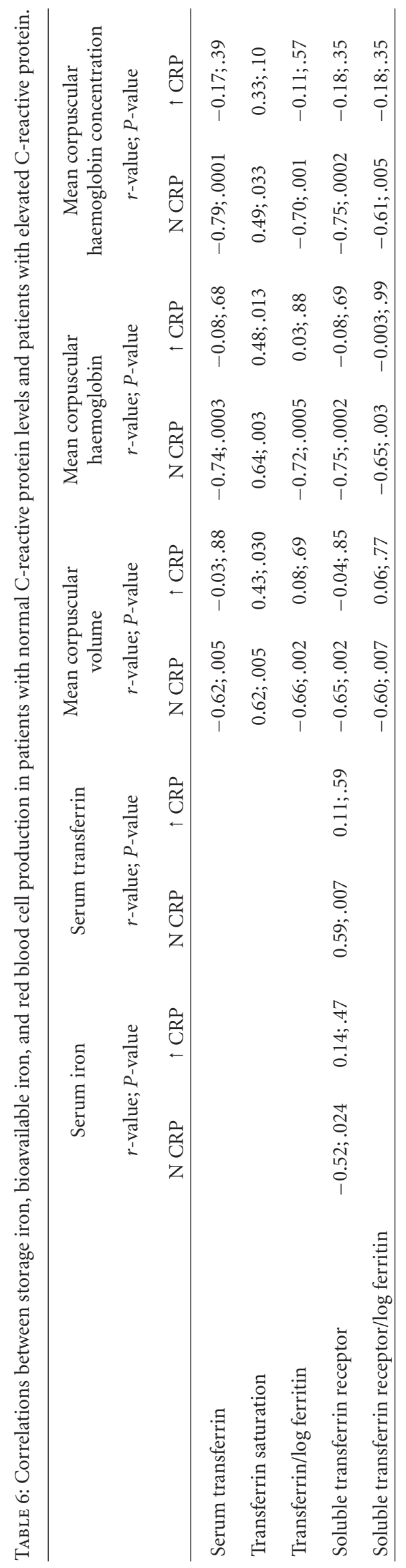




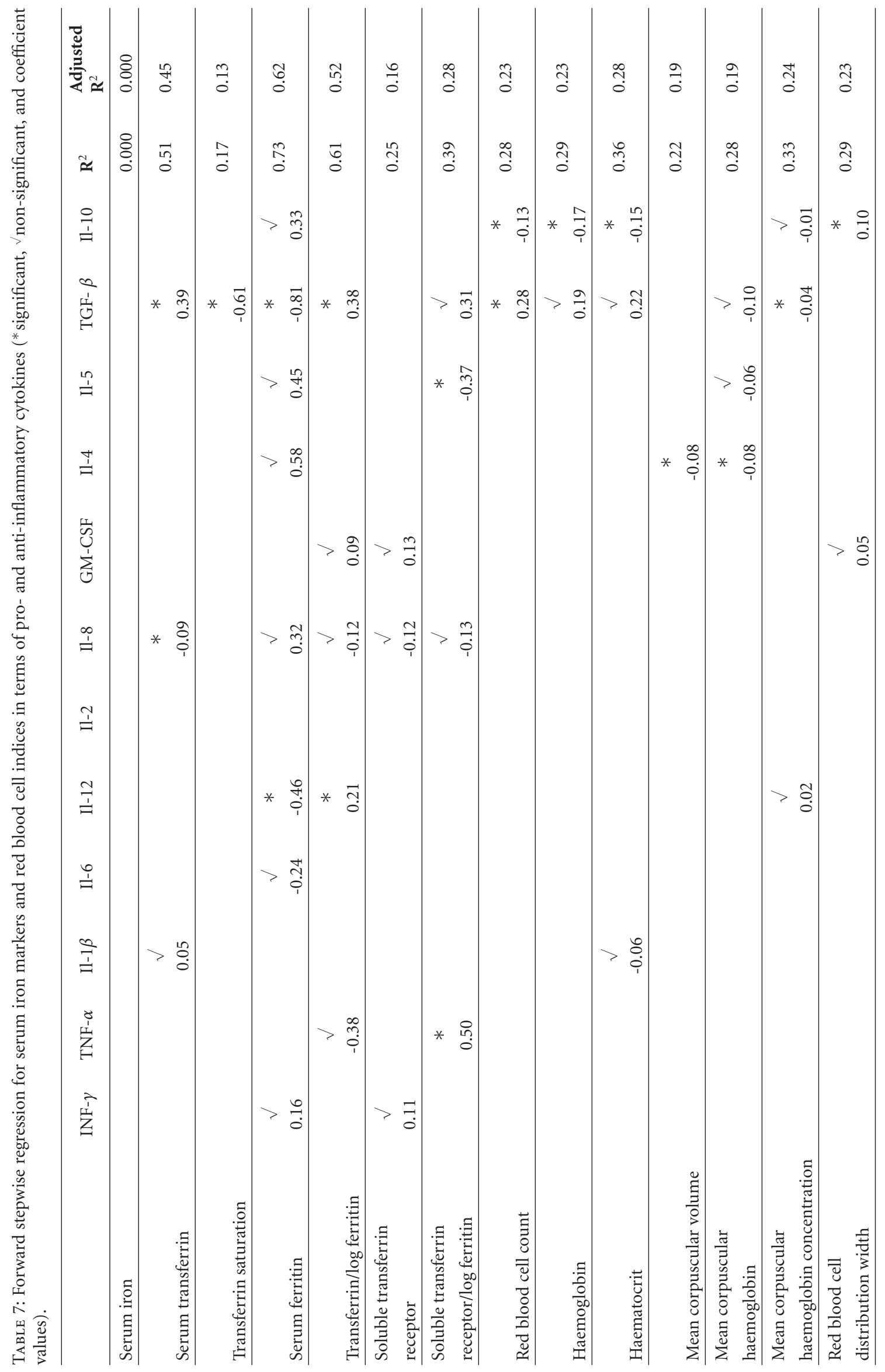


elevated C-reactive protein and the patients with normal C-reactive protein. However, Il-10, was significantly higher in the group with elevated C-reactive protein. This finding is in agreement with previous indications that the antiinflammatory cytokine interleukin-10 can contribute to the hypoferraemia of chronic immune stimulation by upregulating the transcription and translation of ferritin and by stimulating the expression of the haemoglobin scavenger receptor, CD163 $[6,18]$.

The above results supported the notion that T-helper cell type-1/proinflammatory cytokines are the major role players in the development of an iron transfer block. However, indications such as the raised levels of Il-10 and the observation that the iron transfer block was also seen in a number of patients with normal C-reactive protein levels, support previous suggestions $[6,18]$ that T-helper cell type-2 cytokines also play a role in the development/maintenance of an iron transfer block.

Regression analysis showed both serum transferrin and serum ferritin to be highly associated with the levels of a number of cytokines. For the proinflammatory cytokine, Il8 , there was a significant association with serum transferrin, with an increase in Il-8 related to a reduction in transferrin. This is in line with the assumed roles of the proinflammatory cytokines in bringing about a decrease in serum transferrin during chronic immune responses. For the proinflammatory cytokine, Il-12, there was a significant association with serum ferritin, with an increase in ferritin related to a decrease in Il-12. This might be explained by the possible immunosuppressive role of ferritin in HIV/AIDS [34]. In the present study, no significant difference were found for TGF- $\beta$ levels between the patients with elevated Creactive protein and patients with normal C-reactive protein. However, in the patients with elevated C-reactive protein it was shown that both transferrin and ferritin levels were related to TGF- $\beta$ levels. TGF- $\beta$ levels were positively related to transferrin levels and negatively to ferritin levels. This may perhaps suggest TGF- $\beta$ to play a role in control of the proinflammatory response.

\section{Conclusions}

Patients with elevated C-reactive protein levels have a predominantly proinflammatory cytokine profile. C-reactive protein levels are thus a good general reflection of proinflammatory status. The majority, but not all, of patients with high C-reactive protein have an iron transfer block. The results support previous indications that, during chronic immune stimulation, the anti-inflammatory cytokine, Il-10, contributes to reducing bioavailable iron. The proinflammatory cytokine Il- 8 might be involved in decreasing of transferrin. Ferritin, as an immunosuppressive agent, may play a role in the decrease of Il-12 production. TGF- $\beta$ appears to play a role in the control of the proinflammatory response. During overt proinflammatory conditions the normal relationships between storage iron, bioavailable iron, and red blood cell indices are disrupted and iron bioavailability may lose its role as major determinant of the red blood cell profile. The latter finding has implications for the administration of iron to patients with ACD.

\section{References}

[1] X. Alvarez-Hernandez, J. Licéaga, I. C. McKay, and J. H. Brock, "Induction of hypoferremia and modulation of macrophage iron metabolism by tumor necrosis factor," Laboratory Investigation, vol. 61, no. 3, pp. 319-322, 1989.

[2] M. Worwood, "Ferritin," Blood Reviews, vol. 4, no. 4, pp. 259269, 1990.

[3] M. Fahmy and S. P. Young, "Modulation of iron metabolism in monocyte cell line U937 by inflammatory cytokines: changes in transferrin uptake, iron handling and ferritin mRNA," Biochemical Journal, vol. 296, no. 1, pp. 175-181, 1993.

[4] C. A. Finch, H. A. Huebers, M. Cazzola, G. Bergamaschi, and V. Bellotti, "Storage iron," in Ferritins and Isoferritins as Biochemical Markers, A. Albertini, P. Arosio, E. Chiancone, and J. Drysdale, Eds., pp. 3-21, Elsevier Science Publishers, Amsterdam, The Netherlands, 1984.

[5] D. A. Lipschitz, M. O. Simon, S. R. Lynch, J. Dugard, T. H. Bothwell, and R. W. Charlton, "Some factors affecting the release of iron from reticuloendothelial cells," British Journal of Haematology, vol. 21, no. 3, pp. 289-303, 1971.

[6] G. Weiss and L. T. Goodnough, "Anemia of chronic disease," The New England Journal of Medicine, vol. 352, no. 10, pp. 1011-1059, 2005.

[7] G. Semrin, D. S. Fishman, A. Bousvaros et al., "Impaired intestinal iron absorption in Crohn's disease correlates with disease activity and markers of inflammation," Inflammatory Bowel Diseases, vol. 12, no. 12, pp. 1101-1106, 2006.

[8] J. Chung, M. Wessling-Resnick, and C. Enns, "Molecular mechanisms and regulation of iron transport," Critical Reviews in Clinical Laboratory Sciences, vol. 40, no. 2, pp. 151182, 2003.

[9] A. Donovan, C. N. Roy, and N. C. Andrews, "The ins and outs of iron homeostasis," Physiology, vol. 21, no. 2, pp. 115-123, 2006.

[10] A. H. Laftah, N. Sharma, M. J. Brookes et al., "Tumour necrosis factor $\alpha$ causes hypoferraemia and reduced intestinal iron absorption in mice," Biochemical Journal, vol. 397, no. 1, pp. 61-67, 2006.

[11] T. Ganz, "Hepcidin in iron metabolism," Current Opinion in Hematology, vol. 11, no. 4, pp. 251-254, 2004.

[12] J. V. Castell, M. J. Gomez-Lechon, M. David et al., "Interleukin-6 is the major regulator of acute phase protein synthesis in adult human hepatocytes," FEBS Letters, vol. 242, no. 2, pp. 237-239, 1989.

[13] I. N. Alekseeva, "Acute phase blood proteins: role in the homeostasis and their synthesis induction in the liver," Fiziolohichnyi Zhurnal, vol. 40, no. 1, pp. 106-117, 1994.

[14] S. J. Wigmore, K. C. H. Fearon, J. P. Maingay, P. B. S. Lai, and J. A. Ross, "Interleukin-8 can mediate acute-phase protein production by isolated human hepatocytes," American Journal of Physiology, vol. 273, no. 4, pp. E720-E726, 1997.

[15] X. Alvarez-Hernandez, M. V. Felstein, and J. H. Brock, "The relationship between iron release, ferritin synthesis and intracellular iron distribution in mouse peritoneal macrophages. Evidence for a reduced level of metabolically available iron in elicited macrophages," Biochimica et Biophysica Acta, vol. 886, no. 2, pp. 214-222, 1986. 
[16] L. L. Miller, S. C. Miller, S. V. Torti, Y. Tsuji, and F. M. Torti, "Iron-independent induction of ferritin $\mathrm{H}$ chain by tumor necrosis factor," Proceedings of the National Academy of Sciences of the United States of America, vol. 88, no. 11, pp. 4946-4950, 1991.

[17] J. T. Rogers, "Ferritin translation by interleukin-1 and interleukin-6: the role of sequences upstream of the start codons of the heavy and light subunit genes," Blood, vol. 87, no. 6, pp. 2525-2537, 1996.

[18] S. Ludwiczek, E. Aigner, I. Theurl, and G. Weiss, "Cytokinemediated regulation of iron transport in human monocytic cells," Blood, vol. 101, no. 10, pp. 4148-4154, 2003.

[19] R. Deicher and W. H. Hörl, "New insights into the regulation of iron homeostasis," European Journal of Clinical Investigation, vol. 36, no. 5, pp. 301-309, 2006.

[20] C. Oliver, "Fixation and embedding," in Methods in Molecular Biology, L. C. Javois, Ed., vol. 34 of Immunocytochemical Methods and Protocols, pp. 291-298, Humana Press, Totowa, NJ, USA, 1994.

[21] S. B. Rosalki, “C-reactive protein," International Journal of Clinical Practice, vol. 55, no. 4, pp. 269-270, 2001.

[22] J. E. Volanakis, "Human C-reactive protein: expression, structure, and function," Molecular Immunology, vol. 38, no. 2-3, pp. 189-197, 2001.

[23] C. Murr, B. Widner, B. Wirleitner, and D. Fuchs, "Neopterin as a marker for immune system activation," Current Drug Metabolism, vol. 3, no. 2, pp. 175-187, 2002.

[24] D. Fuchs, A. Hausen, G. Reibnegger et al., "Immune activation and the anaemia associated with chronic inflammatory disorders," European Journal of Haematology, vol. 46, no. 2, pp. 6570, 1991.

[25] M. Jongen-Lavrencic, H. R. M. Peeters, G. Vreugdenhil, and A. J. G. Swaak, "Interaction of inflammatory cytokines and erythropoeitin in iron metabolism and erythropoiesis in anaemia of chronic disease," Clinical Rheumatology, vol. 14, no. 5, pp. 519-525, 1995.

[26] R. L. Jurado, "Iron, infections, and anemia of inflammation," Clinical Infectious Diseases, vol. 25, no. 4, pp. 888-895, 1997.

[27] J. H. Brock, "Iron in infection, immunity, inflammation and neoplasia," in Iron Metabolism in Health and Disease, J. H. Brock, J. W. Halliday, M. J. Pippard, and L. W. Powell, Eds., pp. 353-389, W.B. Saunders, London, UK, 1994.

[28] F. M. Pieracci and P. S. Barie, "Diagnosis and management of iron-related anemias in critical illness," Critical Care Medicine, vol. 34, no. 7, pp. 1898-1905, 2006.

[29] G. M. Brittenham, "The red cell cycle," in Iron Metabolism in Health and Disease, J. H. Brock, J. W. Halliday, M. J. Pippard, and L. W. Powell, Eds., pp. 31-62, W.B. Saunders, London, UK, 1994.

[30] I. Cavill, "Erythropoiesis and iron," Best Practice \& Research: Clinical Haematology, vol. 15, no. 2, pp. 399-409, 2002.

[31] E. Baker and E. H. Morgan, "Iron transport," in Iron Metabolism in Health and Disease, J. H. Brock, J. W. Halliday, M. J. Pippard, and L. W. Powell, Eds., pp. 63-95, W.B. Saunders, London, UK, 1994.

[32] M. Kryworuchko and J. Thèze, "Interleukin-2: from T cell growth and homeostasis to immune reconstitution of HIV patients," Vitamins and Hormones, vol. 74, pp. 531-547, 2006.
[33] G. Nunnari, L. Nigro, F. Palermo, D. Leto, R. J. Pomerantz, and B. Cacopardo, "Reduction of serum melatonin levels in HIV1-infected individuals' parallel disease progression: correlation with serum interleukin-12 levels," Infection, vol. 31, no. 6, pp. 379-382, 2003.

[34] J. M. Wigginton, "Reversal of ferritin-mediated immunosuppression by levamisole: a rationale for its application to management of the acquired immune deficiency syndrome (AIDS)," Medical Hypotheses, vol. 44, no. 2, pp. 85-88, 1995. 


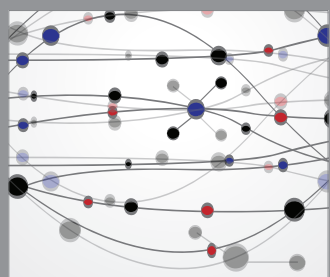

The Scientific World Journal
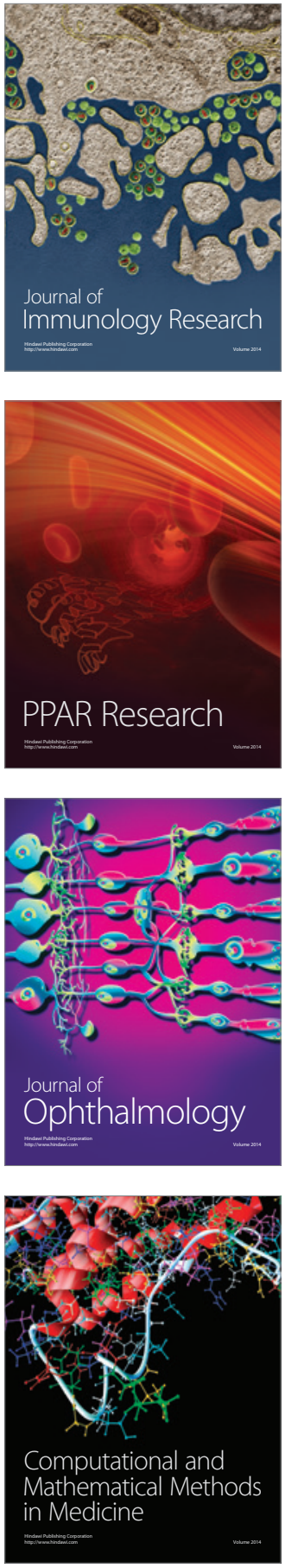

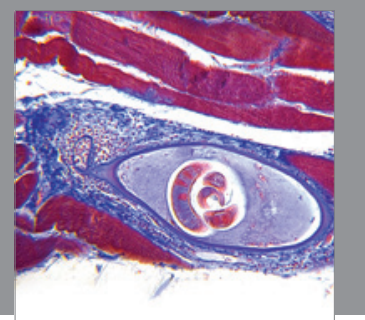

Gastroenterology

Research and Practice
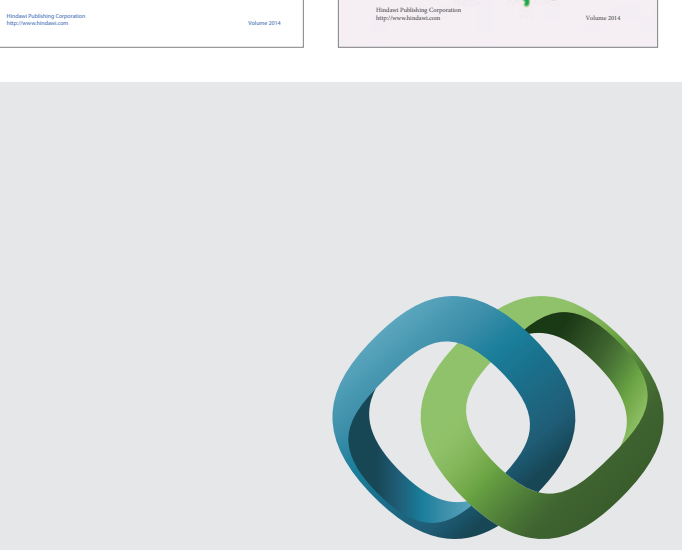

\section{Hindawi}

Submit your manuscripts at

http://www.hindawi.com
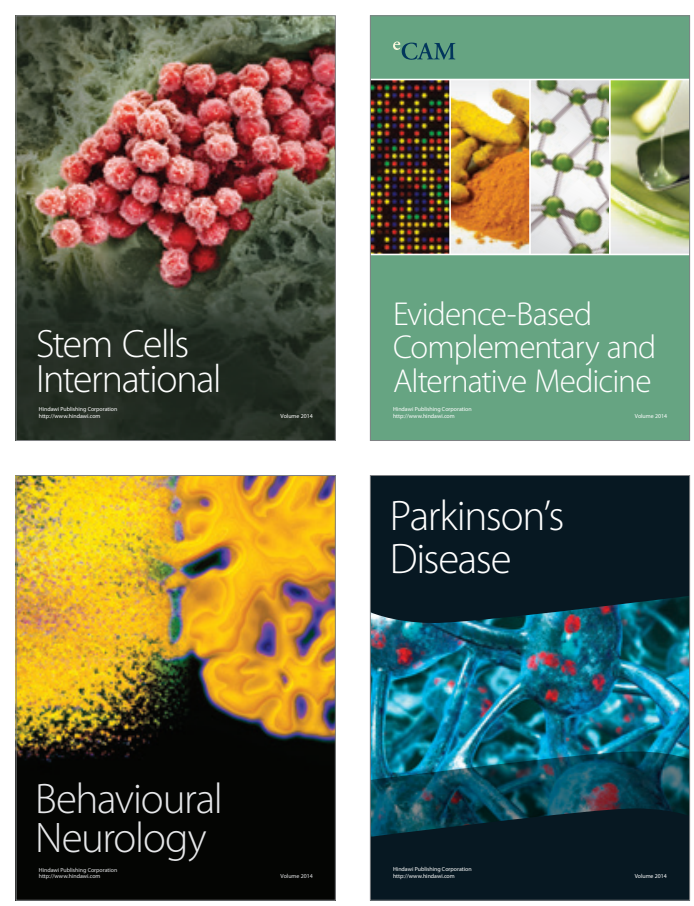

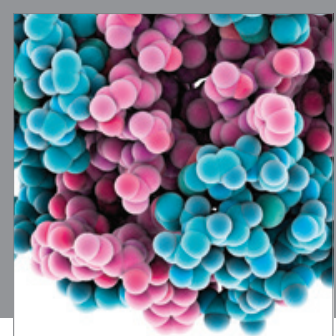

Journal of
Diabetes Research

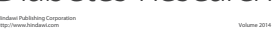

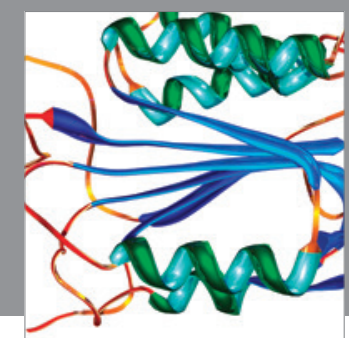

Disease Markers
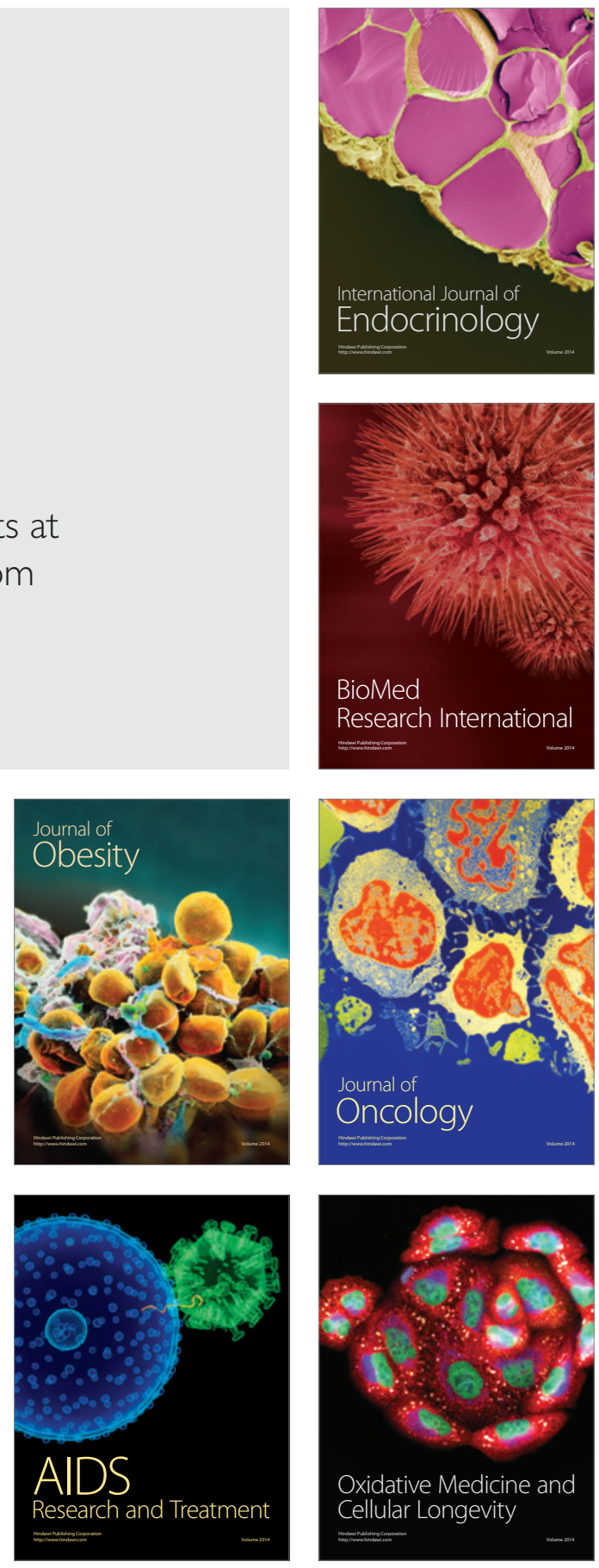